ISSN 0258-7122 (Print), 2408-8293 (Online)

Bangladesh J. Agril. Res. 44(1): 115-126, March 2019

\title{
PROFITABILITY ANALYSIS OF PAPAYA CULTIVATION IN SOME SELECTED AREAS OF BANGLADESH
}

\author{
M. I. KAYSAR ${ }^{1}$, M. S. HOQ ${ }^{2}$, M. W. ISLAM ${ }^{3}$ \\ M. S. ISLAM ${ }^{4}$ AND M.T. ISLAM ${ }^{5}$
}

\begin{abstract}
The study was conducted to depict the overall economics of papaya cultivation in four districts namely Tangail, Jashore, Bandarban and Rajshahi. The objectives of the study were to examine the cost structure, resource use productivities, profitability and the problems of papaya production. A total of 152 farmers taking 38 from each district were selected randomly. Data were collected through a pre-tested interview schedule during January-March, 2017. The per hectare use of human labour, plant protection, manures and fertilizer were found to be maximum at Jashore whereas, the per hectare use of saplings was found to be maximum at Tangail district. The per hectare cost of cultivation of papaya was high at Jossere (365405) followed by Tangail (Tk.334261), Rajshahi (Tk.319754), and Bandarban (Tk. 272664). The average per hectare yield were maximum at Jossere (62MT) followed by Rajshahi (55MT), Tangail (54MT) and Bandarban (52MT). Per hectare gross margin was the highest at Tangail (Tk. 802797) followed by Bandarban (Tk. 658441), Jashore (Tk. 536346) and Rajshahi (Tk.471298). Per hectare net return was highest at Tangail (Tk.633738) followed by Bandarban (Tk.507335), Jossere (Tk.346594) and Rajshahi (Tk.302747). The overall benefit cost ratio was 2.39 which indicates papaya cultivation was profitable in Bangladesh. The yield of papaya would increase by $0.0407,0.125,00.0627,0.0863$ and $0.3785 \%$ if papaya farmers apply $1 \%$ additional human labour, seedlings/saplings, fertilizer, improved variety, and dummy for loamy soil. Attacks on viral disease, adverse weather condition, non-availability of reliable seed, lack of irrigation facilities, lack of technical knowledge and problems in marketing of papaya were the major constraints of papaya cultivation in the study areas.
\end{abstract}

\section{Introduction}

Agriculture is the most dominant sector of the national economy of Bangladesh contributing nearly $17 \%$ of national income. On the other hand, about $45 \%$ of the population depends for their subsistence and livelihood on the agriculture sector (BBS, 2016). A number of crops are being cultivated in different parts of the country due to varying agro-climatic conditions. Among various fruits, papaya is

\footnotetext{
${ }^{1 \& 2}$ Scientific officer, Agricultural Economics Division, Bangladesh Agricultural Research Institute (BARI), Gazipur-1701, ${ }^{3}$ Lecturer, Department of Agribusiness, Atish Dipankar University of Science \&Technology, ${ }^{4}$ Agricultural Economics Division, Bangladesh Sugarcrop Research Institute (BSRI), Ishwardi-6621, ${ }^{5}$ Scientific officer, Pomology Division, Horticulture Research Centre, BARI, Gazipur-1701, Bangladesh.
} 
one of the important fruits which is cultivated all over the country. The plants are of medium height $(180-220 \mathrm{~cm})$ and fruits are of medium to large size $(1-2 \mathrm{~kg})$ (BARI, 2014). The taste is superb with excellent quality. The ripe fresh fruits of papaya are eaten throughout the tropics, while unripe fruits are commonly used as vegetables for cooking. Every 100 gms of papaya contains 2020 I.U. vitamin A, $40 \mathrm{mg}$ vitamin $\mathrm{C}, 10 \mathrm{mg}$ calcium, 10 mgphosphorus, $9.5 \mathrm{gms}$ of carbohydrates, and 0.5 gms of proteins (Sharma and Singh, 1990).

Papaya is a crop which has versatile uses. Raw papayas can be used for making salted pickles, while fully developed but somewhat raw fruits are used to make a perfect jelly, jam, candy, nectar, puree, concentrate, slab, powder, toffee, tuttifrutti, freeze dried chunks, dried rolls, dried slices are some other products that are made from papaya fruit (Garde, 1997). Now a days papain extraction from unripe fruits of papaya is one of the most important use. Papain is the dried latex from the fruit, containing a protein hydrolyzing enzyme which has a number of specific technological functions viz., food and beverage preparations, pharmaceutical applications, textile industries and garment cleaning ( Kumar and Saha, 1997).

Although climatic conditions of Bangladesh topapaya production. It is cultivated on large scale in Jashore, Rajshahi, Kustia, Tangail, Khulna and hill tracts. The national production of papaya is 332093 metric tons with an area of 14547 acres in 2015-2016 (BBS, 2016).

Table 1. Area and production of papaya at different years

\begin{tabular}{r|c|c|c|c}
\hline \multirow{2}{*}{ year } & \multicolumn{2}{|c|}{ Green papaya } & \multicolumn{2}{c}{ Ripe papaya } \\
\cline { 2 - 5 } & Area(Acres) & $\begin{array}{c}\text { Production(M. } \\
\text { tons) }\end{array}$ & Area(Acres) & Production(M. tons) \\
\hline $2013-14$ & 3973 & 207244 & 3021 & 130596 \\
$2014-15$ & 5690 & 198724 & 3126 & 133370 \\
$2015-16$ & 4786 & 201722 & 9761 & 130371 \\
\hline
\end{tabular}

Source: Yearbook of Agricultural Statistics, 2016.

A good number of papaya varieties grown in Bangladesh such as Red lady, Top lady, Coorg honeydew, Washington, Ranchi, Shahi Papaya Kashimpur, and some exotic varieties. Papaya being a high value crop has got tremendous scope to increase the income of farmers with its high yield potential .Since no serious attempts have been found to know, a large number of farmers throughout the country are still unwilling to cultivate improved papaya varieties. It is important to know the farm level adoption of different varieties, their costs, returns, profitability, per hectare yield, per metric ton cost of production, and constraints faced by growers. Keeping all this points in mind the present study was under taken with following specific Objectives:

To know the cultivation practices of papaya in different locations

$>$ To estimate the profitability of papaya cultivation; 
To examine the resource use efficiency by using Cobb-Douglas production function;

$>$ To identify constraints and problems of papaya production and to suggest appropriate policy measures.

\section{Methodology}

\subsection{Sampling procedure and sample size}

The study was conducted in four districts of Bangladesh namely Tangail, Jashore, Bandarban and Rajshahi. Then one upazila from each district and two blocks from each upazila were purposively selected in consultation with DAE personnel and papaya scientists. Finally, a total of 160 farmers, taking 40 from each district were randomly selected for the study (Table 2).

Table 2. Study areas and respondent farmers

\begin{tabular}{|c|c|c|c|c|}
\hline S1. No. & $\begin{array}{c}\text { Name of } \\
\text { district }\end{array}$ & Name of upazila & Name ofagril. block & No. of farmer \\
\hline \multirow[t]{2}{*}{1} & Tangail & Madhupur & Magandinagar & 20 \\
\hline & & & Orunkhula & 20 \\
\hline \multirow[t]{2}{*}{2} & Jossere & Jhikargacha & Godkhali & 20 \\
\hline & & & Horinagar & 20 \\
\hline \multirow[t]{2}{*}{3} & Bandarban & Bandarbansadar & Tumcopara & 20 \\
\hline & & & kuhalong & 20 \\
\hline \multirow[t]{3}{*}{4} & Rajshahi & Paba & Parila & 20 \\
\hline & & & hargram & 20 \\
\hline & & Total & & 160 \\
\hline
\end{tabular}

\subsection{Data collection}

The primary data like farm family, infrastructure, land utilization, cropping pattern, input use, farm production, papaya grading, packaging and transport in marketing cost, and problems of cultivation and marketing of papaya were collected by personal interview with the sample respondents. The data related to the year 2016-2017 were collected by survey method with the help of a pre specially designed comprehensive and pre-tested interview schedule.

\subsection{Analytical techniques}

Collected data were edited, summarized, tabulated and analyzed to fulfill the objectives of the study. Descriptive statistics using different statistical tolls like averages, percentages and ratios were used for presentation of the results of the study. The profitability of papaya production was examined on the basis of gross return, gross margin and benefit cost ratio analysis (Boardma, 1996). Besides, the 
opportunity costs of family supplied labour were taken into consideration in estimating total cost. Land use cost was calculated on the basis of per year lease value of land.

\subsubsection{Profitability analysis}

The following equations were used to estimate the profitability of papaya cultivation at farm level.

Equations for cost analysis:

Variable cost $=\sum_{I=1}^{n}(x i j p i j)$

$$
\begin{aligned}
& \text { TVCij }=\text { VCij + IOCij } \\
& \text { TCij }=\text { TVCij + TFCij }
\end{aligned}
$$

Where, $\mathrm{TCij}=$ Total cost of $\mathrm{jth}$ crop for ith farmer $(\mathrm{Tk} / \mathrm{ha})$

TVCij $=$ Total variable cost of $j^{\text {th }}$ crop for $\mathrm{i}^{\text {th }}$ farmer (Tk/ha).

TFCij $=$ Total fixed cost of $j^{\text {th }}$ crop for $\mathrm{i}^{\text {th }}$ farmer $(\mathrm{Tk} / \mathrm{ha})$

$\mathrm{VCij}=$ Variable cost of $\mathrm{j}^{\text {th }}$ crop for $\mathrm{i}^{\text {th }}$ farmer $(\mathrm{Tk} / \mathrm{ha})$

IOCij $=$ Interest of operating capital of $j^{\text {th }}$ crop for $i^{\text {th }}$ farmer $(\mathrm{Tk} / \mathrm{ha})$

$\mathrm{Xij}=$ Quantity of inputs of $\mathrm{j}^{\text {th }}$ crop for $\mathrm{i}^{\text {th }}$ farmer $(\mathrm{kg})$

$\mathrm{Pij}=$ Price of inputs of $\mathrm{j}^{\text {th }}$ crop for $\mathrm{i}^{\text {th }}$ farmer $(\mathrm{Tk} / \mathrm{kg})$

$\mathrm{J}=$ Number of crops

$\mathrm{i}=$ Number of farmers $(1.2 .3 \ldots \ldots . . \mathrm{n})$

Equations for profitability analysis

Gross return $=\mathrm{GRij}=\mathrm{Yij} \mathrm{Pij}$

Net return $=$ GRij - TCij

Gross margin $=$ GRij - VCij

Where,

GRij $=$ Gross return of $j^{\text {th }}$ crop for $\mathrm{i}^{\text {th }}$ farmer (Tk/ha)

Pij $=$ Price $(T k / h a)$ of $j^{\text {th }}$ crops received by $i^{\text {th }}$ farmer

Yij $=$ Quantity $(\mathrm{kg} / \mathrm{ha})$ produced of $\mathrm{j}^{\text {th }}$ crop for $\mathrm{i}^{\text {th }}$ farmer.

\subsubsection{Choice of function}

The empirical evidences form the previous studies suggested that to study the relationship between crop output and input variables, the following CobbDouglas production function was used.

$\mathrm{Y}=\mathrm{a} \mathrm{X} \mathrm{X}_{1}^{\mathrm{b} 1} \cdot \mathrm{X}_{2}^{\mathrm{b} 2} \ldots \ldots . \mathrm{X}_{\mathrm{n}}^{\mathrm{bn}} \cdot \mathrm{e}^{\mu}$ 
In the logarithmic transformation, the function becomes linear one. This function allows constant, increasing or decreasing return to scale. In this function ' $b_{1}$ ' is the elasticity of production of factor $\mathrm{X}_{1}$, and can be used directly irrespective of units of measurement. The function in logarithmic form is expressed as follows.

$\log Y=\log a+b_{1} \log X_{1}+b_{2} \log X_{2}+\ldots .+b_{n} \log X_{n}+\mu \log e$

\subsubsection{Selection of variables}

Nine independent variables were considered as important contributors to the production of papaya. The equation fitted was of the following form (Kapase, 1992).

$\mathrm{Y}=\mathrm{a} . \mathrm{X}_{1}^{\mathrm{b} 1} \mathrm{X}_{2}^{\mathrm{b} 2} \mathrm{X}_{3}^{\mathrm{b} 3} \mathrm{X}_{4}^{\mathrm{b} 4} \mathrm{X}_{5}^{\mathrm{b} 5} \mathrm{X}_{6}{ }^{\mathrm{b} 6} \mathrm{X}_{7}^{\mathrm{b} 7} \mathrm{X}_{8}{ }^{\mathrm{b} 8} \mathrm{X}_{9}{ }^{\mathrm{b} 9} \mathrm{e}^{\mu}$

i.e. $\log Y=\log a+b_{1} \log X_{1}+b_{2} \log X_{2}+b_{4} \log X_{4}+b_{3} \log X_{3}+b_{5} \log X_{5}+$ $b_{6} \log X_{6}+b_{7} \log X_{7}+b_{8} \log X_{8}+b_{9} \log X_{9}+\mu \log e$

where,

i) Dependent variable

$\mathrm{Y}=$ Yield of papaya (MT/ha)

ii) Independent variable

$\mathrm{X}_{1}=$ Land preparation cost (Tk./ha)

$\mathrm{X}_{2}=$ Quantity of fertilizer $(\mathrm{kg})$

$\mathrm{X}_{3}=$ Quantity of manures $(\mathrm{kg})$

$\mathrm{X}_{4}=$ Total human labour (in man days)

$\mathrm{X}_{5}=$ Seedlings/saplings cost $(\mathrm{Tk} / \mathrm{ha})$

$\mathrm{X}_{6}=$ Expenditure on plant protection $(\mathrm{Tk} . / \mathrm{ha})$

$\mathrm{X}_{7}=$ Irrigation (No.)

$\mathrm{X}_{8}=$ Dummy for soil type $(1=$ Loam, $0=$ otherwise

$\mathrm{X}_{9}=$ Dummy for papaya variety $(1=$ improved, $0=$ otherwise $)$

a $=$ Intercept term (constant)

bi $=$ Regression coefficient or elasticity of production $(1=1, \ldots .9)$

$e^{\mu}=$ Error term

The estimated production function was statistically tested with the help of 't' test and 'F' value.

\section{Results and Discussion}

\subsection{Production practices of papaya at different location}

Papaya farmers in the study areas used different types of varieties such shahi papaya, red lady, top lady, Indian and different local varieties. On an average $28 \%$ farmers used local variety. Among different locations $45 \%$ farmers in Tangail districts used local variety because farmers established their garden in pineapple orchard. The maximum $(60 \%)$ gardens were established on plain land 
in all areas which was $78 \%$ farmers choose sandy loamy soil for papaya cultivation. Planting was done during monsoon season in the study area. Papayas are planted in pits of $50 \mathrm{~cm} \times 50 \mathrm{~cm} \times 50 \mathrm{~cm}$ size in a square system with spacing of $2 \mathrm{~m} \times 2 \mathrm{~m}$ accommodating 10442 plants/ha. Before planting, the farmers filled pits with 10-15 kg decomposed farm yard manure that mixed with surface soil. In the study area the sample farmers irrigated 7-8 times in their papaya garden. The responded papaya growers mainly cultivated ginger, turmeric, pineapple, banana, chili and different leguminous crop as inter crops.

Table 3. Cultivation practices of papaya in farmers field at different locations

\begin{tabular}{|c|c|c|c|c|c|}
\hline \multirow{2}{*}{ Production practice } & \multicolumn{5}{|c|}{ Locations } \\
\hline & Tangail & Jossere & Bandarban & Rajshahi & All areas \\
\hline \multicolumn{6}{|l|}{ 1.Varity used (\% of farmers) } \\
\hline Local variety & 45 & 30 & 24 & 16 & 28 \\
\hline Shahi papaya & 18 & 26 & 15 & 58 & 29 \\
\hline Red lady & 10 & 18 & 30 & 12 & 18 \\
\hline Top lady & 7 & 9 & 8 & 5 & 7 \\
\hline Others hybrid & 20 & 17 & 23 & 7 & 17 \\
\hline \multicolumn{6}{|l|}{$\begin{array}{l}\text { 2. Types of land: (\%)High } \\
\text { land }\end{array}$} \\
\hline Medium high land & 50 & 20 & 60 & 30 & 40 \\
\hline Plain land & 50 & 80 & 40 & 70 & 60 \\
\hline \multicolumn{6}{|l|}{ 3. Types of soil: (\%) } \\
\hline \multicolumn{6}{|l|}{ Sandy soil } \\
\hline Loamy soil & 30 & 20 & & 40 & 22 \\
\hline Sandy loamy soil & 70 & 80 & 100 & 60 & 78 \\
\hline \multicolumn{6}{|l|}{ 4. Sources of seedling: $(\%)$} \\
\hline Own garden & 30 & 30 & & 35 & 24 \\
\hline Market/neighbor & 70 & 60 & 50 & 65 & 61 \\
\hline BADC/Others & & 10 & 50 & & 15 \\
\hline 5. Planting time & $\begin{array}{l}\text { March- } \\
\text { April }\end{array}$ & $\begin{array}{l}\text { March- } \\
\text { April }\end{array}$ & $\begin{array}{l}\text { March- } \\
\text { April }\end{array}$ & $\begin{array}{l}\text { March- } \\
\text { April }\end{array}$ & $\begin{array}{l}\text { March- } \\
\text { April }\end{array}$ \\
\hline 6. No. of saplings /ha & 10560 & 10860 & 10000 & 10350 & 10442 \\
\hline 7. Age of saplings (days) & $40-60$ & $40-60$ & $40-60$ & $40-60$ & $40-60$ \\
\hline $\begin{array}{l}\text { 8.Plant to plant } \\
\text { distance(meters) }\end{array}$ & 1.8 & 1.7 & 2.3 & 1.9 & 1.93 \\
\hline 9.Depth of pit (c.m.) & 45 & 45 & 45 & 45 & 45 \\
\hline 10. Weeding (No./year) & 10 & 12 & 8 & 10 & 10 \\
\hline 11. Spraying (times) & 2.5 & 3.6 & 1.8 & 3.4 & 2.8 \\
\hline 12. Irrigation (No./year) & 8 & 8.5 & 5.3 & 9.5 & 7.8 \\
\hline Intercrop and relay crop & $\begin{array}{l}\text { Ginger, } \\
\text { turmeric, } \\
\text { pineapple, } \\
\text { banana }\end{array}$ & $\begin{array}{l}\text { Brinjal, } \\
\text { chilli }\end{array}$ & $\begin{array}{l}\text { Ginger, } \\
\text { turmeric } \\
\text { Banana, } \\
\text { chilli }\end{array}$ & $\begin{array}{l}\text { Chilli, } \\
\text { brinjal, } \\
\text { Banana } \\
\text { pulse }\end{array}$ & $\begin{array}{l}\text { Ginger, } \\
\text { turmeric, } \\
\text { pineapple, } \\
\text { banana, } \\
\text { chilli }\end{array}$ \\
\hline
\end{tabular}

Source: Field survey, 2017. 


\subsection{Input Utilization}

Uses of various inputs directly affect the cost of cultivation. Papaya farmers use different inputs like human labour, machinery, seeds, saplings, manures, fertilizers, irrigation, plant protection etc. in their garden. The information regarding per hectare inputs utilization for papaya cultivation of selected farms of different size groups is presented in Table 4.

Table 4. Input use pattern per hectare for papaya cultivation.

\begin{tabular}{l|c|c|c|c|c|c}
\hline \multirow{2}{*}{ Particulars } & \multirow{2}{*}{ Units } & \multicolumn{5}{|c}{ Actual utilization level on different locations } \\
\cline { 3 - 7 } & & Tangail & Jossere & Bandarban & Rajshahi & All areas \\
\hline Human labour & man days & 185 & 204 & 162 & 187 & 184 \\
Family labour & & 105 & 120 & 100 & 80 & 101 \\
Hired labour & & 80 & 84 & 62 & 107 & 83 \\
Power tiller cost & $\mathrm{Tk}$ & 6000 & 6526 & 5580 & 6850 & 6239 \\
Manures & $\mathrm{kg}$ & 45000 & 65504 & 23309 & 57046 & 47714 \\
Fertilizers & & & & & & \\
Urea & $\mathrm{kg}$ & 1470 & 1560 & 705 & 1091 & 1207 \\
MoP & $\mathrm{kg}$ & 980 & 780 & 650 & 830 & 810 \\
TSP & $\mathrm{kg}$ & 1210 & 1380 & 1210 & 1208 & 1252 \\
Gypsum & $\mathrm{kg}$ & 750 & 812 & 713 & 755 & 757 \\
Boric acid & $\mathrm{kg}$ & 96 & 105 & 92 & 85 & 94 \\
Zinc sulfate & $\mathrm{kg}$ & 74 & 82 & 86 & 88 & 83 \\
Irrigation & $\mathrm{No}$ & 8 & 8.5 & 5.3 & 9.5 & 7.8 \\
Plant protection cost & $\mathrm{Tk}$. & 6362 & 6820 & 6750 & 6138 & 6517 \\
\hline
\end{tabular}

Source: Field survey, 2017.

Fertilizers should be applied in time to achieve good yield. The doses of fertilizers should be applied depending on the variety and initial soil fertility. Urea (450-500) gm and MP (450-500) gm per plant should be applied as split application. Urea $(50 \mathrm{gm})$ and MP $(50 \mathrm{gm})$ should be applied per plant one month interval commencing from one month after plant. The fertilizer doses should be double after flowering. The average quantity of manures applied by the farmers was worked out as $47714 \mathrm{~kg}$ per hectare. Human labour was required for land development, plantation of sapling, application of manures and fertilizers, spraying, weeding, irrigation and harvesting. On an average, 184 man-days of human labour was required for papaya cultivation of which $55 \%$ was family supplied and $45 \%$ was hired labour. The average application of fertilizers per hectare in terms of urea1207kg, MoP $810 \mathrm{~kg}$, TSP $1252 \mathrm{~kg}$, gypsum $757 \mathrm{~kg}$, boric acid $94 \mathrm{~kg}$ and zinc sulfate $83 \mathrm{~kg}$ were applied. The average number of irrigation was 7.8 per hectare. The number of irrigation in case of Tangail, Jashore, Bandarban and Rajshahi were 8, 8.5, 5.3 and 9.5 in numbers, respectively. Plant protection in monetary terms was Tk.6517, while it was the highest at Jashore (Tk. 6820)and the lowest at Rajshahi (Tk. 6138). 


\subsection{Cost of cultivation}

Planting materials, land preparation, input cost (FYM, fertilizers, plant growth regulators, plant protection chemicals etc.), labour cost, power cost, harvesting, packing and transportation charges were the cost components for papaya cultivation. Rental value of land was treated as fixed cost and interest on operating capital was also considered for the estimation of papaya cultivation cost. On average farmers spend Tk. 6239/ha for land preparation by using power tiller/tractor. The highest manures cost was observed Tk. 49128/ha at Jashore followed by Rajshahi (Tk. 42784/ha), Tangail (Tk. 33750/ha) and Bandarban (Tk. 23309/ha). Per hectare average saplings cost was Tk.31327 which was the highest in Jashore (Tk.32580) and lowest in Bandarban (Tk3000).Among variable costs human labour cost was the highest in all study areas. The highest human labour cost was observed (Tk. 57120/ha) at Jashore and lowest (Tk. 40500/ha) in Bandarban. The overall rental value of land was Tk.30374/ha. The interest on fixed cost and interest on operating cost was calculated @ of 8\% basis. Among four locations the highest total cost was found Tk. 365405/ha at Jashore and lowest inBandarbanTk.272664/ha.

Table 5. Per hectare cost of cultivation of papaya in different locations

\begin{tabular}{l|c|c|c|c|c|c}
\hline \multicolumn{1}{c}{ Cost heading } & Tangail & Jossere & Bandarban & Rajshahi & All areas & $\begin{array}{c}\% \text { of } \\
\text { total } \\
\text { cost }\end{array}$ \\
\hline Land preparation & 6000 & 6526 & 5580 & 6850 & 6239 & 1.93 \\
Manures & 33750 & 49128 & 23309 & 42784 & 37242 & 11.53 \\
Human labour* & 51800 & 57120 & 40500 & 48620 & 49509 & 15.33 \\
TSP & 30250 & 34500 & 30250 & 30210 & 31302 & 9.69 \\
Gypsum & 9000 & 9744 & 8556 & 9060 & 9090 & 2.81 \\
Saplings & 31680 & 32580 & 30000 & 31050 & 31327 & 9.70 \\
Urea & 23520 & 24960 & 11280 & 17456 & 19304 & 5.98 \\
Mop & 16660 & 13260 & 11050 & 14110 & 13770 & 4.26 \\
Boric acid & 17280 & 18900 & 16560 & 15300 & 17010 & 5.27 \\
Zinc sulfate & 13320 & 14760 & 15480 & 15840 & 14850 & 4.59 \\
Irrigation & 10956 & 10620 & 8360 & 10311 & 10061 & 3.11 \\
Plant protection cost & 6362 & 6820 & 6750 & 6138 & 6517 & 2.02 \\
Bamboo and fencing & 20000 & 24000 & 14652 & 17920 & 19143 & 5.93 \\
Transportation & 2300 & 2420 & 2140 & 2360 & 2305 & 0.71 \\
Miscellaneous expense & 3623 & 3000 & 3000 & 3560 & 3295 & 1.02 \\
Interest on operating & 22120 & 24667 & 18197 & 21725 & 21677 & 6.72 \\
capital & & & & & & \\
Rental value of land & 35639 & 32399 & 26999 & 26460 & 30374 & 9.40 \\
Total cost & 334261 & 365405 & 272664 & 319755 & 323018 & 100 \\
\hline *Human labour cost & & & & & & \\
\hline
\end{tabular}

*Human labour cost included expenditure on land development, farm layout, digging of pits, filling of pits and application of inputs. 


\subsection{Profitability of papaya cultivation}

Input-output ratio indicates the rate at which the expenses on different inputs and factors are paid for. It also indicates the degree of profitability in relation to expenditure. The output input relationship worked out at the different cost concepts indicates the ratio between the gross income and cost showing the returns per taka invested. The output-input ratio in papaya cultivation in different locations is shown in the table 6. After 3-5 months of garden age, papaya production started and its continue up to twelve months. Farmers marked two categories of papaya such as green papaya as vegetables and ripe papaya as fruit. Prices of both categories depend on quality and seasonality of production. In the last year farmers got the average price of green papaya Tk. 8.87 per $\mathrm{kg}$ and ripe papaya tk. 19.5 per kg. Per hectare highest yield was found 60MT at Jossere followed by Rajshahi (55MT), Tangail (54MT) and Bandarban (52MT). The highest gross return was estimated at Tk. 968000 for Tangail followed by Bandarban (Tk. 780000), Jashore (Tk. 712000) and Rajshahi (Tk. 622500). Average gross margin was estimated Tk.622500. Net return was highest Tk. 633738 at Tangail followed by Bandarban (Tk.507335), Jashore (Tk.346594) and Rajshahi (Tk.302745). Average BCR was 2.39 which was than one meaning that papaya cultivation was a profitable farm business at farmers' level in the study areas (Table 6).

Table 6. Yield level, farm harvest price and gross income per hectare at different locations

\begin{tabular}{l|c|c|c|c|c}
\hline Locations & $\begin{array}{c}\text { Yield } \\
\text { (green } \\
\text { papaya) } \\
\text { MT/ha }\end{array}$ & $\begin{array}{l}\text { Yield } \\
\text { (ripe papaya) } \\
\text { MT/ha }\end{array}$ & $\begin{array}{l}\text { Harvest price } \\
\text { (green) Tk./MT }\end{array}$ & $\begin{array}{l}\text { Harvest price } \\
\text { (ripe) Tk/MT }\end{array}$ & $\begin{array}{l}\text { Gross output } \\
\text { (Tk./ha) }\end{array}$ \\
\hline Tangail & 20 & 34 & 11000 & 22000 & 968000 \\
Jashore & 35 & 27 & 8000 & 16000 & 712000 \\
Bandarban & 28 & 24 & 9000 & 22000 & 780000 \\
Rajshahi & 35 & 20 & 7500 & 18000 & 622500 \\
All areas & 29.5 & 26.25 & 8875 & 19500 & 773688.5 \\
\hline
\end{tabular}

Source: Field survey, 2017.

\subsection{Factors affecting papaya production}

Papaya production at farm level is influenced by different variables. The estimates of the parameters of the Cobb-Douglas production function for papaya are presented in Table 7. The coefficients of the variables in the function are the elasticity of average output with respect to the different inputs used in papaya production. 
Table 7. Profitability analysis of papaya cultivation at different locations

\begin{tabular}{|c|c|c|c|c|c|}
\hline \multirow{2}{*}{ Items } & \multicolumn{5}{|c|}{ Locations } \\
\hline & Tangail & Jessore & Bandarban & Rajshahi & All areas \\
\hline A. Total cost (TC) & 334261 & 365405 & 272664 & 319754 & 323018 \\
\hline $\begin{array}{l}\text { b. Total variable } \\
\text { cost (TVC) }\end{array}$ & 165202 & 175653 & 121558 & 151202 & 153401 \\
\hline $\begin{array}{l}\text { Gross } \\
\text { return(Tk./ha) }\end{array}$ & 968000 & 712000 & 780000 & 622500 & 773687 \\
\hline $\begin{array}{l}\text { Gross } \\
\operatorname{margin}(\mathrm{Tk} . / \mathrm{ha})\end{array}$ & 802797 & 536346 & 658441 & 471298 & 620286 \\
\hline Net return(Tk./ha) & 633738 & 346594 & 507335 & 302745 & 450668 \\
\hline $\begin{array}{l}\mathrm{BCR} \text { (cash cost } \\
\text { basis) }\end{array}$ & 5.86 & 4.05 & 6.42 & 4.12 & 5.04 \\
\hline $\begin{array}{l}\text { BCR (Full cost } \\
\text { basis) }\end{array}$ & 2.89 & 1.95 & 2.86 & 1.94 & 2.39 \\
\hline
\end{tabular}

Table 8. Regression coefficient and coefficient of multiple determinations for papaya

\begin{tabular}{|c|c|c|c|c|c|}
\hline \multirow{2}{*}{ Variables } & \multicolumn{4}{|c|}{ Locations } & \multirow[b]{2}{*}{ All areas } \\
\hline & Tangail & Jossere & Bandarban & Rajshahi & \\
\hline Constant & 3.43 & 4.34 & 5.68 & 3.23 & 3.36 \\
\hline Land preparation cost (Tk.) & 0.0231 & 0.0265 & 0.0023 & 0.0365 & 0.0298 \\
\hline Fertilizer(kg) & $0.0326^{*}$ & $0.0112^{* *}$ & $0.0134^{*}$ & $0.0637^{* *}$ & $0.0627^{* *}$ \\
\hline Manures (kg) & 0.0365 & 0.0277 & 0.02568 & 0.0586 & 0.0624 \\
\hline Human labour (days) & $0.0425^{* *}$ & $0.0301^{* *}$ & $0.02365^{* *}$ & $0.0389^{* *}$ & $0.0407^{* *}$ \\
\hline $\begin{array}{l}\text { Seedlings/saplings cost } \\
\text { (Tk) }\end{array}$ & $0.0236^{*}$ & $0.1861^{*}$ & $0.0365^{*}$ & $0.0129^{*}$ & $0.125^{*}$ \\
\hline $\begin{array}{l}\text { Plant protection chemicals } \\
(\mathrm{Tk})\end{array}$ & 0.06325 & 0.0925 & 0.0864 & 0.0962 & 0.0913 \\
\hline Irrigation (No.) & 0.0362 & 0.3730 & $0.7802^{* *}$ & $0.7562^{* *}$ & 0.0213 \\
\hline $\begin{array}{l}\text { Dummy for soil type }(1= \\
\text { Loam, } 0=\text { otherwise }\end{array}$ & $0.0985^{*}$ & $0.0785^{*}$ & $0.0986^{*}$ & $0.8752^{*}$ & $0.0863^{*}$ \\
\hline $\begin{array}{l}\text { Dummy for papaya variety } \\
(1=\text { improved, } 0= \\
\text { otherwise) }\end{array}$ & $0.8562^{* * *}$ & $0.965^{* * *}$ & $0.3562^{* * *}$ & $0.3689^{* * *}$ & $0.3785^{\text {*** }}$ \\
\hline $\mathrm{R}^{2}$ & 75 & 84 & 82 & 79 & 82 \\
\hline F value & 89 & 91 & 84 & 95 & 93 \\
\hline
\end{tabular}

The empirical results indicated that the coefficients of human labour, seedlings, fertilizer, papaya variety, and soil type had positive and significant impacts on papaya production at farm level. The yield of papaya would increase by 0.0407 , $0.125,0.0627,0.0863$ and $0.3785 \%$ if papaya farmers use $1 \%$ additional human labour, seedlings/saplings, fertilizer, papaya variety, and loamy soil. More or less similar results regarding significant variables were found in the Cobb-Douglas production function models estimated of papaya production in the study areas. 
Table 9. Constraints faced by farmers at different locations

\begin{tabular}{|c|c|c|c|c|c|}
\hline \multirow{2}{*}{ Constraints } & \multicolumn{5}{|c|}{$\%$ farmers responded } \\
\hline & Tangail & Jossere & Bandarban & Rajshahi & All areas \\
\hline $\begin{array}{l}\text { Do not protected crop from adverse } \\
\text { weather }\end{array}$ & 80 & 85 & 86 & 85 & 84.0 \\
\hline No proper control for viral disease & 70 & 90 & 89 & 85 & 83.5 \\
\hline $\begin{array}{l}\text { Do not know the name, proper method } \\
\text { and doses of pesticides and } \\
\text { insecticides }\end{array}$ & 70 & 75 & 85 & 76 & 76.5 \\
\hline Problems in marketing of papaya & 60 & 80 & 60 & 85 & 71.3 \\
\hline $\begin{array}{l}\text { No direction and encouragement from } \\
\text { local administration for papaya } \\
\text { cultivation }\end{array}$ & 60 & 63 & 72 & 50 & 61.3 \\
\hline Non availability of quality seedling & 60 & 50 & 60 & 55 & 56.3 \\
\hline Lack of capital & 50 & 45 & 80 & 50 & 56.3 \\
\hline $\begin{array}{l}\text { Do not know the name and proper } \\
\text { doses of manures and fertilizers }\end{array}$ & 50 & 60 & 72 & 40 & 55.5 \\
\hline Non-availability of institutional loan & 50 & 56 & 62 & 40 & 52.0 \\
\hline Lack of irrigation facilities & 40 & 30 & 70 & 65 & 51.3 \\
\hline $\begin{array}{l}\text { Lack of technical know-how for } \\
\text { papaya cultivation }\end{array}$ & 45 & 40 & 70 & 42 & 49.3 \\
\hline Problems of intercultural operations & 30 & 35 & 26 & 28 & 29.8 \\
\hline
\end{tabular}

Source: Field survey, 2017

\subsection{Constraints to cultivation of papaya}

The constraints relating to different resources reported by the sample farmers in the production of papaya are depicted in Table 8 . It is observed that $56 \%$ sample farmers did not get reliable quality seedlings in time while, $83 \%$ of the sample farmers reported to non-availability of viral disease resistant seed to which was very dreadful to crop. Forty nine per cent of selected farmers complained about lack of knowledge about production technology. Non- availability of pesticides on time and lack of knowledge about its use were opined by $76 \%$ sample growers, while 55\% stated that they did not know the name and proper doses of manures and fertilizers. Papaya growing is capital intensive enterprise that why 56\% of sample farmers complained about inadequate capital. Eighty four per cent of the sample farmers reported that they could protect their garden from adverse weather condition and $71 \%$ farmers claimed that marketing of papaya was a serious problem. Farmers did not get proper price when peak period. Irrigation facilities were not adequate in the study areas mentioned by $51 \%$ farmers as a problem. 


\section{Conclusions and Recommendations}

\subsection{Conclusions}

The study was conducted for understanding the present situation of papaya cultivation in Bangladesh. This study examined the production practices of papaya at different locations. It also gives clear picture of papaya cultivation in hill regions and plain land. Highest cost item was found human labour cost followed by fertilizer cost and saplings cost. Mostly family labour was used for papaya cultivation. The gross margin, net margin and benefit cost ratio indicated that farmers were benefited from cultivation of papaya in all areas. Human labour, seedlings, fertilizer, improved papaya variety, and loamy soil had positive and significant impacts on papaya production at farm level. In production of papaya, growers faced the problems of non-availability and high prices of quality seedlings, shortage of labour and no proper control over viral disease. While low price of papaya, fluctuating prices, higher transportation cost etc. were reported to be major problems of papaya cultivation in the study areas.

\subsection{Recommendations}

$>$ Papaya growers cultivate exotic varieties which are much susceptible to virus diseases so farmers need suitable high yielding and virus resistant variety of papaya.

$>$ Regular training should be arranged for the farmers to developing their knowledge about improved cultivation practices and adaptation of new technology.

Fertilizers and plant protection chemicals price should be reduced.

\section{References}

BARI. 2014. Handbook of Agricultural Technology, $6^{\text {th }}$ edition. Bangladesh Agricultural Research Institute, Gazipur

BBS. 2016. Statistical Yearbook of Bangladesh. Bangladesh Bureau of statistics, Ministry of planning, Dhaka. Bangladesh.

Boardman, A.E., Greenberg, D.H., Viking A.R., and Weimer D.L. 1996. Cost Benefit Analysis: concepts and practice. Englewood cliffs, NJ: prentice hall.

Gadre, N. A. 1997. Economics of production of papaya for papain extraction, PKV Res. J. 21 (2): 142-145.

Kapase, P. M. 1992. Differentials in resource use structure and productivities of principal crops in different agro climatic zones of Maharashtra. Unpublished Ph.D. Dissertation submitted to M.P.K.V., Rahuri, India.

Kumar, S. and Sahu, D.1997.Commercializing papaya cultivation as potential as agro industries, Farmers and Parliament, 37(10): 7-22

Sharma, C. K. and Singh, I. P. 1990. Tips of papaya growing for Tripura, Farmers and Parliament, 25 (3): 17-25. 